https://nv.nltu.edu.ua

https://doi.org/10.15421/40290524

Article received $21.05 .2019 \mathrm{p}$.

Article accepted 30.05.2019 p.

удк 614.844.5

$@ \bowtie$ Correspondence author

I. G. Stylyk

stilik_i@undicz.dsns.gov.ua

І. Г. Стилик, В. С. Бенедюк, В. В. Присяжнюк, М. В. Осадчук

Украйнський науково-дослідний інститут циивільного захисту, м. Київ, Украӥна

\title{
ПРОВЕДЕННЯ ВИПРОБУВАНЬ ПІНОУТВОРЮВАЧІВ ЗАГАЛЬНОГО ПРИЗНАЧЕННЯ ДЛЯ ГАСІННЯ ПОЖЕЖ
}

\begin{abstract}
Відповідно до "Плану випробувальних і дослідних робіт Дослідно-випробувальних лабораторій ГУ(У) ДСНС України в областях і м. Києві " між Науково-дослідним центром "Пожежна безпека" та дослідно-випробувальними лабораторіями проведено міжлабораторні порівняльні випробування зразків піноутворювача загального призначення. Проаналізовано отримані дані, що дало змогу виявити значні розбіжності в отриманих результатах між дослідно-випробувальними лабораторіями та випробувальним центром. Виявлено основні причини виникнення розбіжностей у результатах порівняльних випробувань шляхом проведення повторного раунду випробувань на базі УкрНДЩЗ із застосуванням лабораторних піногенераторів 3 різними конструктивними особливостями. Проведено експериментальні дослідження з визначення кратності піни середньої кратності, отриманої за допомогою лабораторних піногенераторів з різними конструктивними особливостями за умови використання однакових зразків піноутворювача загального призначення. Встановлено, що в разі встановлення на різні піногенератори однакових сіток, кратність піни стає подібною у всіх піногенераторах. 3'ясовано, що інші конструктивні відмінності піногенераторів на результати випробувань також впливають, тому в подальшому існує потреба в проведенні додаткових досліджень з визначення впливу інших конструктивних відмінностей піногенераторів на результати випробувань, а також потрібно провести аналогічні випробування із використанням піногенераторів інших дослідно-випробувальних лабораторій. Технічні рішення, направлені на вдосконалення конструктивних особливостей сіток піно генераторів, приведуть до створення кращої піни щодо її вогнегасних здатностей та підвищення іiї ефективності під час гасіння пожеж у лісах.
\end{abstract}

Ключові слова: піноутворювач; кратність та стійкість піни; випробувальне устатковання; лісові пожежі.

Вступ. Збільшення антропогенного навантаження на лісові екосистеми та зміна клімату зумовлює посилення роботи з охорони лісів від пожеж (Zalesov, 2013). Розроблення ефективних систем і вдосконалення способів пожежогасіння $є$ одним 3 найважливіших завдань підрозділів й ДСНС. Одним із засобів, які використовують для ліквідації таких пожеж, є вогнегасна піна. Генерація піни здійснюється за допомогою додавання піноутворювача до води. Одним з важливих показників якості піноутворювачів загального призначення для гасіння пожеж є кратність піни середньої кратності. Загальні вимоги щодо проведення випробувань за цим показником описано у DSTU 3789:2015, який був розроблений на заміну DSTU 3789-98. Однією з відмінностей між DSTU 3789-2015 та DSTU 3789-98:1999), яка спрямована на забезпечення збіжності результатів випробувань, $\epsilon$ наявність в останньому деталізованого креслення лабораторного піногенератора, призначеного для отримання піни. Відповідно до "Плану випробувальних i дослідних робіт ДВЛ ГУ(У) ДСНС України в областях і м. Києві" між Науково-дослідним центром "Пожежна
Безпека" та дослідно-випробувальними лабораторіями проводили міжлабораторні порівняльні випробування зразків піноутворювача загального призначення відповідно до DSTU 3789-2015. Проаналізувавши отримані дані, виявлено значні розбіжності в отриманих результатах між дослідно-випробувальними лабораторіями та випробувальним центром.

Мета дослідження - визначення причин розбіжностей у результатах порівняльних випробувань шляхом проведення повторного раунду випробувань на базі УкрНДІЦЗ із застосуванням лабораторних піногенераторів 3 різними конструктивними особливостями та прийняття подальших технічних рішень для їх розроблення 3 метою підвищення ефективності використання піни для боротьбі з лісними пожежами.

Об'єкт дослідження - кратність піни. Предмет дослідження - вплив конструктивних особливостей лабораторного піногенератора на результати випробувань 3 визначення кратності піни.

Результати дослідження. У ході досліджень застосовували чотири лабораторні піногенератори, а саме:

Інформація про авторів:

Стилик Irop Геннадійович, інженер, сектор метрологiї. Email: stilik_i@undicz.dsns.gov.ua; https://orcid.org/0000-0002-8474-2014

Бенедюк Вадим Степанович, ст. наук. співробітник, відділ вогнезахисту та пожежогасніння науково-випробувального центру.

Email: BENEDYUK_V@undicz.dsns.gov.ua; https://orcid.org/0000-0002-5109-5295

Присяжнюк Віталій В'ячеславович, начальник відділу вогнезахисту та пожежогасіння.

Email: Prisyazhnuk1979@gmail.com; https://orcid.org/0000-0002-9780-785X

Осадчук Максим Віталійович, мол. наук. співробітник, відділ вогнезахисту та пожежогасіння. Email: maximus_fire@meta.ua; https://orcid.org/0000-0002-4584-3541

Цитування за Дсту: Стилик І. Г., Бенедюк В. С., Присяжнюк В. В., Осадчук М. В. Проведення випробувань піноутворювачів загального призначення для гасіння пожеж. Науковий вісник НЛтУ України. 2019, т. 29, № 5. С. 120-122.

Citation APA: Stylyk, I. G., Benedyuk, V. S., \& Prysyazhnuk, V. V., Osadchuk M. V. (2019). On the Issue of Testing General Purpose foam Generators for Fire Fighting. Scientific Bulletin of UNFU, 29(5), 120-122. https://doi.org/10.15421/40290524 
один піногенератор Науково-дослідного центру "ПОЖЕЖНА БЕЗПЕКА" та три піногенератори з ДВЛ ГУ ДСНС України в Одеській та Миколаївській областях, а також обладнання згідно з (DSTU 3789-2015, 2015), що застосовується для проведення випробувань піноутворювачів загального призначення для гасіння пожеж за показником кратності та стійкості піни.

Зовнішній вигляд піногенераторів представлено на рис. 1.

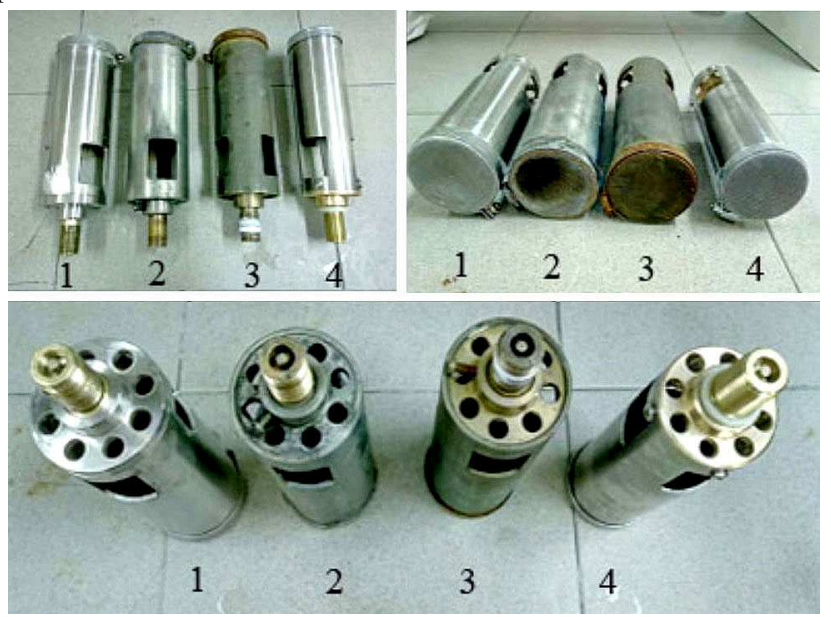

Рис. 1. Зовнішній вигляд лабораторних піногенераторів, що застосовували у ході досліджень: 1) піногенератор, наданий ДВЛ ГУ ДСНС України в Миколаївській області (№ 1); 2) піногенератор НДЦ "Пожежна безпека" (№ 2); 3, 4) піногенератори, надані ДВЛ ГУ ДСНС України в Одеській області (№ 3 та 4)

Результати аналізу конструктивного виконання та габаритних розмірів піногенераторів, згідно з кресленнями, наведеними в (DSTU 3789-2015, 2015), представлено в табл. 1.

Табл. 1. Відмінності у конструктивному виконанні та габаритних розмірах піногенераторів

\begin{tabular}{|c|c|}
\hline Фактичний параметр & Вимога ДСТУ \\
\hline \multicolumn{2}{|c|}{ Піногенератор № 1} \\
\hline Наявність різьби в направляючій & - \\
\hline Наявність різьби на шайбі & - \\
\hline $\begin{array}{l}\text { Сітка (номінальний розмір сторо- } \\
\text { ни чарунки менший за } 0,5 \text { мм) }\end{array}$ & $\begin{array}{c}\text { Номінальний розмір сто- } \\
\text { рони чарунки } 0,5 \text { мм }\end{array}$ \\
\hline $\begin{array}{l}\text { Три вибірки на шайбі радіусом } \\
2 \text { мм кожна }\end{array}$ & $\begin{array}{l}\text { Три вибірки на шайбі ра- } \\
\text { діусом } 2,25 \text { мм кожна }\end{array}$ \\
\hline \multicolumn{2}{|c|}{ Піногенератор № 2} \\
\hline $\begin{array}{l}\text { Відповідає вимогам (DSTU 3789- } \\
\text { 2015. 2015) }\end{array}$ & - \\
\hline \multicolumn{2}{|c|}{ Піногенератор № 3} \\
\hline На шайбі виготовлено 4 вибірки & 3 вибірки \\
\hline \multicolumn{2}{|c|}{ Піногенератор № 4} \\
\hline $\begin{array}{l}\text { Сітка (номінальний розмір сторо- } \\
\text { ни чарунки більший за } 0,5 \text { мм) }\end{array}$ & $\begin{array}{c}\text { Номінальний розмір сто- } \\
\text { рони чарунки } 0,5 \text { мм }\end{array}$ \\
\hline овнішній діаметр стакана 58 мм & $65 \mathrm{MM}$ \\
\hline Внутрішній діаметр стакана 56 & MM \\
\hline
\end{tabular}

У ході проведеного порівняльного аналізу конструктивного виконання піногенераторів виявлено відхилення від вимог (DSTU 3789-2015, 2015) у трьох із чотирьох піногенераторів з умовними позначеннями № 1, № 3, № 4. На рис. 2 зображено основні елементи піногенератора відповідно до (DSTU 3789-2015).

Перед проведенням досліджень 3 визначення кратності піни середньої кратності було визначено гідравлічний тиск, за якого піногенератори будуть забезпечувати витрату робочого розчину $\left(66^{ \pm 3}\right) \mathrm{cm}^{3} / \mathrm{c}^{3}$ згідно 3 (DSTU 3789-2015, 2015) (табл. 2).

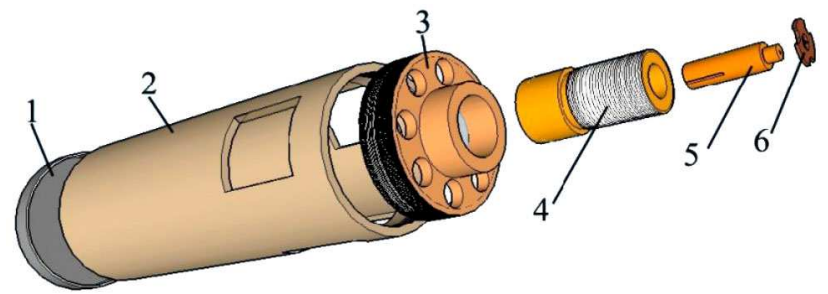

Рис. 2. Основні елементи піногенератора: 1) сітка 05 ГОСТ 3826 ; 2) стакан; 3) направляюча; 4) корпус; 5) розпилювач; 6) шайба

Табл. 2. Результати досліджень 3 визначення гідравлічного тиску та витрати робочого розчину

\begin{tabular}{|c|c|c|}
\hline $\begin{array}{c}\text { Піногенера- } \\
\text { тор }\end{array}$ & Тиск, бар & $\begin{array}{c}\text { Фактична витрата робочого ро3- } \\
\text { чину, } \text { cм}^{3} / \mathrm{c}\end{array}$ \\
\hline № 1 & $6,0^{ \pm 0,2}$ & 68 \\
\hline № 2 & $7,0^{ \pm 0,2}$ & 68 \\
\hline № 3 & $7,0^{ \pm 0,2}$ & 66 \\
\hline № 4 & $7,0^{ \pm 0,2}$ & 69 \\
\hline
\end{tabular}

Порівняльні дослідження кратності піни проводили на установці для визначення кратності та стійкості піни середньої кратності, що експлуатується в УкрНДІЦЗ, з використанням водного розчину піноутворювача загального призначення "Софір" у такій послідовності:

1) визначення кратності піни середньої кратності, утвореної із піногенератора № 2;

2) визначення кратності піни середньої кратності, утвореної із піногенератора № 1;

3) визначення кратності піни середньої кратності, утвореної із піногенератора № 3;

4) визначення кратності піни середньої кратності, утвореної із піногенератора № 4.

Результати порівняльних досліджень кратності піни наведено в табл. 3 .

Табл. 3. Результати порівняльних досліджень 3 визначення кратності піни для піногенераторів № 1-4

\begin{tabular}{|c|c|c|c|c|c|}
\hline \begin{tabular}{|c|}
$\begin{array}{c}\text { Піногене- } \\
\text { ратор }\end{array}$ \\
\end{tabular} & $\begin{array}{c}\text { № } \\
\text { досліду }\end{array}$ & $\begin{array}{c}\text { Tиск, } \\
\text { бар } \\
\end{array}$ & \begin{tabular}{|c|} 
Витрата, \\
$\mathrm{cm}^{3} / \mathrm{c}$
\end{tabular} & $\begin{array}{c}\text { Фактична } \\
\text { кратність піни } \\
\end{array}$ & \begin{tabular}{|l|} 
Середній \\
результат \\
\end{tabular} \\
\hline \multirow{2}{*}{ № 2} & 1 & $7^{ \pm 0,2}$ & 68 & 161 & \multirow{2}{*}{160} \\
\hline & 2 & $7^{ \pm 0,2}$ & 67 & 159 & \\
\hline \multirow{2}{*}{ № 1} & 1 & $6^{ \pm 0,2}$ & 68 & 54 & \multirow{2}{*}{55} \\
\hline & 2 & $6^{ \pm 0,2}$ & 69 & 55 & \\
\hline \multirow{2}{*}{ № 3} & 1 & $7^{ \pm 0,2}$ & 67 & 137 & \multirow{2}{*}{136} \\
\hline & 2 & $7^{ \pm 0,2}$ & 66 & 135 & \\
\hline \multirow{2}{*}{ № 4} & 1 & $7^{ \pm 0,2}$ & 68 & 84 & \multirow{2}{*}{85} \\
\hline & 2 & $7^{ \pm 0,2}$ & 69 & 86 & \\
\hline
\end{tabular}

Як видно із результатів досліджень, наведених в табл. 3, піна, яка була отримана за допомогою піногенераторів № 1 та 4 має кратність, яка істотно відрізняється від кратності піни, отриманої з інших піногенераторів № 2 та 4. Це пов'язано із тим, що піногенератори № 2 та 3 мають у своїй конструкції сітку з однаковими номінальними розмірами чарунок, а у піногенераторів № 1 та 4 сітки мають інші номінальні розміри. Водночас, сітка в піногенераторі відіграє важливу роль, тому що саме на ній відбувається формування піни 3 крапель робочого розчину піноутворювача, які потрапляючи на сітку, утворюють плівку, з якої утворюють бульбашки піни. За рахунок набутої кінетичної енергії змішаний потік ежектованого повітря та розчину піноутворювача, виштовхує піну з сітки піногенератора. Більш детально процеси генерування піни відображені у роботах (Kovalishin, 2011; Tihomirov, 1983).

Після заміни сіток в піногенераторах № 1 та 4 було проведено повторні дослідження з визначення кратності, результати яких наведено в табл. 4. 
Табл. 4. Результати порівняльних досліджень з визначення кратності піни для піногенераторів № 1 та 4 після заміни сітки

\begin{tabular}{|c|c|c|c|c|c|}
\hline $\begin{array}{l}\text { Піноге- } \\
\text { нератор }\end{array}$ & $\begin{array}{c}\text { № } \\
\text { дослі- } \\
\text { ду }\end{array}$ & $\begin{array}{c}\text { Тиск, } \\
\text { бар }\end{array}$ & $\begin{array}{c}\text { Витрата, } \\
\mathrm{cm}^{3} / \mathrm{c}\end{array}$ & $\begin{array}{c}\text { Фактична } \\
\text { кратність піни }\end{array}$ & $\begin{array}{l}\text { Середній } \\
\text { результат }\end{array}$ \\
\hline \multirow{2}{*}{ № 2} & 1 & 7 & 67 & 158 & \multirow{2}{*}{159} \\
\hline & 2 & 7 & 66 & 160 & \\
\hline \multirow{2}{*}{ № 1} & 1 & 6 & 67 & 157 & \multirow{2}{*}{157} \\
\hline & 2 & 6 & 68 & 156 & \\
\hline \multirow{2}{*}{ № 3} & 1 & 7 & 68 & 139 & \multirow{2}{*}{139} \\
\hline & 2 & 7 & 67 & 138 & \\
\hline \multirow{2}{*}{ № 4} & 1 & 7 & 69 & 180 & \multirow{2}{*}{182} \\
\hline & 2 & 7 & 68 & 183 & \\
\hline
\end{tabular}

Як видно із результатів досліджень, наведених в табл. 4, найкращий результат щодо збіжності по відношенню один до одного, після заміни сітки, відзначається для лабораторних піногенераторів № 1 та 2, а найгірший для піногенераторів № 3 та 4 .

Висновки. Визначено, що конструктивні особливості лабораторних піногенераторів впливають на результати випробувань щодо кратності піни. Найвагоміший вклад у цю розбіжність вносить сітка, на якій генерується піна. Технічні рішення, спрямовані на вдоско- налення конструктивних особливостей сіток піногенераторів, приведуть до створення кращої піни щодо іiі вогнегасних здатностей та підвищення іiї ефективності під час гасіння пожеж у лісах.

\section{Перелік використаних джерел}

DSTU 3789-2015. (2015). Pinoutvoryuvachi zagalnogo priznachennya dlya gasinnya pozhezh. Zagalni tehnichni vimogi i metodi viprobuvannya. Kyiv: Derzhstandart. [In Ukrainian].

DSTU 3789-98. (1999). Pinoutvoryuvachi zagalnogo priznachennya dlya gasinnya pozhezh. Zagalni tehnichni vimogi i metodi viprobuvan. Kyiv: Derzhstandart. [In Ukrainian].

Kovalishin, V. V., Ulinets, E. M., GrushovInchuk, O. V., \& Kavetskiy, V. V. (2011). Doslidzhennya zalezhnosti kratnosti povitryano-mehanichnoyi pini vid geometrichnih rozmiriv pinogeneratora. Naukoviy vIsnik UkrNDIPB, 2(24), 74-79. [In Ukrainian].

Tihomirov, V. K. (1983). Penyi. Teoriya i praktika ihpolucheniya $i$ razrusheniya. (2nd ed.). Moscow: Chemistry, 264 p. [In Ukrainian].

Timoshenko, O. M., Boris, O. P., \& Skorobagatko, T. M. (2015). Poshuk perspektivnih naukovo-tehnIchnih rishen $\mathrm{z}$ modernizatsiyi generatora pini serednoyi kratnosti gps-600. Naukoviy visnik UkrNDIPB, 2(32), 55-60. [In Ukrainian].

Zalesov, S. V. (2013). Lesnaya pirologiya. (3rd ed.). Yekaterinburg: Ural. gos. Lesotehn, 333 p. [In Russian].

I. G. Stylyk, V. S. Benedyuk, V. V. Prysyazhnuk, M. V. Osadchuk Ukrainian Scientific Research Institute of Civil Defence, Kyiv, Ukraine

\section{ON THE ISSUE OF TESTING GENERAL PURPOSE FOAM GENERATORS FOR FIRE FIGHTING}

In accordance with the Plan of Testing and Research Work of the Experimental and Testing Laboratories of the Main Department (Department) the State Emergency Service of Ukraine (SESU) in the Regions and in Kyiv", interlaboratory comparative tests of samples of a general purpose foam generator were conducted within FIRE SAFETY Research Centre and experimental laboratories. The analysis of the data was carried out, which allowed detecting significant differences in the results between the experimental testing laboratories and the testing centre. The main reasons for the discrepancy in the results of comparative tests were revealed by conducting a second round of tests on the basis of Ukrainian Scientific Research Institute of Civil Defence with the use of laboratory foam generators with different design features. Experimental investigations have been conducted to determine the multiplicity of foam average multiplicity obtained with the help of laboratory foam generators with different design features, provided that the same samples of a general purpose foaming agent are used. We have found that the results of determining the multiplicity of foam, which were obtained with the help of various foam generators, are significantly different. This is due to the fact that foam generators have in their design a grid with different nominal sizes of cells, in turn, the grid in the foam generator plays an important role, because it is there that the formation of foam from the droplets of the working solution of the foaming agent occurs, falling on the grid, form a film from which the foam bubbles are formed because, due to the acquired kinetic energy, a mixed stream of ejected air and a solution of a foaming agent pushes foam from the grating of the foam generator. It was found that when installed on different foam generators of identical nets, the multiplicity of foam becomes similar in all foam generators. It has been determined that other constructive differences of foam generators also affect the test results. Therefore, in the future, there is a need for additional studies to determine the influence of other constructive differences of foam generators on the test results, as well as to perform similar experiments with the use of foam generators of other experimental testing laboratories. Technical solutions aimed at improving the design features of grid foam generators will cause the formation of better foam, its fire-extinguishing capabilities and increase its efficiency in extinguishing forest fires.

Keywords: foaming agent; multiplicity and resistance of foam; testing equipment; forest fires. 